\title{
Perlawanan Peran Kultural Perempuan Dalam Film Marlina Si Pembunuh Dalam Empat Babak
}

\author{
Vincentia Ananda Arum Permatasari \\ Program Studi Ilmu Komunikasi UNIKA Soegijapranata Semarang \\ email: vincentia.ananda@unika.ac.id
}

\begin{abstract}
The system of patriarchal prevents women from leaving the domestic sphere. However, that does not mean women cannot fight. This study aims to find the discourse of resistance offered by the film Marlina The Murderer in Four Acts. This research uses descriptive qualitative research methods with the discourse analysis approach. Based on the results of the study found that two cultural roles performed by women, namely activities on the bed and activities in the kitchen. Through discourse analysis that sees meaning through text and images based on the themes of the film, it has several conclusions. The cultural role that women have can be used as a force against male domination. Furthermore, women use the way men do to against, which is to be masculine.
\end{abstract}

Keyword: Resistance, Woman, Marlina

\begin{abstract}
Abstrak
Kuatnya sistem patriarki membuat perempuan tidak bisa keluar dari wilayah domestik. Namun, bukan berarti perempuan tidak bisa melawan. Penelitian ini bertujuan untuk melihat wacana perlawanan yang ditawarkan oleh film Marlina Si Pembunuh dalam Empat Babak. Penelitian ini menggunakan metode penelitian kualitatif deskriptif dengan pendekatan analisis wacana. Berdasarkan hasil penelitian ditemukan dua peran kultural yang dilakukan oleh perempuan, yaitu aktivitas di atas kasur dan aktivitas di dalam dapur. Melalui analisis wacana yang melihat makna melalui teks dan gambar berdasarkan tema yang ditawarkan film maka memiliki beberapa kesimpulan. Peran kultural yang dimiliki perempuan dapat digunakan sebagai kekuatan untuk melawan dominasi laki-laki. Selanjutnya, perempuan menggunakan cara yang dilakukan laki-laki untuk melakukan perlawanan, yaitu menjadi maskulin.
\end{abstract}

Kata Kunci: Perlawanan, Perempuan, Marlina

\section{PENDAHULUAN}

"Kalau masih ada waktu tidur dengan kau, kita bertujuh. Sa(ya) itu sering melihat kau gagah tapi selalu sendiri. Malam ini kau dapat bonus tujuh lakilaki memang. Heh, sudah berapa lakilaki yang kau tiduri? Hanya dia? Malam ini kau adalah perempuan paling beruntung."

"Sa(ya) perempuan paling sial sudah malam ini."
"Hah, kau suka sekali jadi korban. Masih setengah jam lagi. Sebentar lagi tamu-tamu yang lain datang. Kau masak makan malam untuk kami”

Dialog di atas adalah cuplikan bagian pembuka Film Marlina Si Pembunuh dalam Empat Babak (MPEB), yang dilakukan oleh Marlina, sebagai tokoh utama perempuan, dan Markus, sebagai tokoh pendukung lakilaki. Adegan ini menceritakan tentang 
Marlina, seorang perempuan yang baru saja ditinggal mati suaminya, didatangi oleh Markus, seorang laki-laki penagih hutang. Melalui dialog tersebut mempertontonkan bagaimana Marlina didudukkan sebagai inferior yang harus mematuhi kekuasaan lakilaki. Marlina menggambarkan situasi idealitas peran kultural sebagai perempuan, yaitu objek seksualitas dan pengelola dapur. Idealitas adalah produk kultural sebagai pelabelan serta pelanggengan dominasi dan kekuasaan (Suseno, 2010). Dalam analisis peran perempuan yang dilakukan dari perspektif posisi mereka dalam berurusan dengan pekerjaan produktif, perempuan yang ditempatkan pada fungsi reproduksi merupakan peran tradisi atau kultural (Hubeis, 2010). Hal ini menyebabkan pandangan idealitas tentang perempuan adalah perempuan yang selalu dikonotasikan pada aktivitas domestik. Perempuan dinilai tidak dapat berkontribusi secara aktif di luar rumah sehingga perannya sekedar aktivitas di dalam rumah. Dapur dan kasur diasosiasikan sebagai aktivitas yang melekat pada perempuan. Peran domestik ini menempatkan perempuan pada status marjinal yang tidak memiliki kuasa atas laki-laki.

Adeney (2004) menyatakan bahwa masyarakat Indonesia sendiri bersifat patriarkal dimana perempuan pada umumnya turun temurun menunjukkan penghormatan mereka terhadap laki-laki. Kaum perempuan kadang-kadang dipandang bukan cuma lebih lemah secara jasmaniah, tetapi juga lebih lemah secara moral dan spiritual. Berdasarkan hal tersebut, kaum laki-laki adalah para pengatur kaum perempuan. Pernyataan Ardeney ini menegaskan bahwa perempuan tidak memiliki kuasa terhadap laki-laki. Terlebih secara kultural perempuan memiliki peran yang berbeda dibandingkan laki-laki.

Pembahasan mengenai praktik kuasa atas gender telah banyak dilakukan, bahkan melalui karya seni. Permatasari (2017) menyatakan bahwa kesadaran mengenai kesetaraan gender tidak hanya milik Barat, tetapi juga ada di Timur. Sehingga pendiskriminasian laki-laki terhadap perempuan banyak tercermin dalam karyakarya sastra Indonesia. Tidak saja karya sastra, kisah dominasi laki-laki pada perempuan juga banyak disajikan melalui karya seni, salah satunya film.

Marlina Si Pembunuh dalam Empat Babak (MPEB) adalah salah satu film yang memuat cerita dengan latar sistem patriarki yang kental. Film ini menjadi lebih menarik karena tidak hanya berkutat pada dominasi laki-laki melainkan justru bercerita pada perjuangan seorang perempuan menuntut ketidakadilan yang menimpanya akibat hegemoni dan tradisi. Film garapan Mouly Surya ini telah memenangkan berbagai penghargaan internasional dan nasional. Diantaranya 
adalah Sebagai Aktris Terbaik di Festival Film Sitges 2017; Grand Prize di Penghargaan Tokyo FILMeX 2017; Best Cinema Film, Best Cinematography, Best Direction Art, Best Film Score, dan Best Actress di Penghargaan Maya 2017; Film Cerita Panjang Terbaik, Sutradara Terbaik, Pemeran Utama Wanita Terbaik, Pemeran Pendukung Wanita Terbaik, Penulis Skenarion Asli Terbaik, Pengarah Sinematografi Terbaik, Penata Musik Terbaik, Penata Sura Terbaik, Penyunting Gambar Terbaik, dan Pengarah Artistik Terbaik dalam Festival Film Indonesia 2018. Selain memenangkan penghargaan, film ini juga menjadi nominasi dalam ajang penghargaa film internasional.

Terlepas dari berbagai prestasi yang diterima oleh Film MPEB, film ini menarik untuk dikaji. Dialog dan gambar yang disajikan mewakili dominasi laki-laki pada perempuan. Namun cerita diakhiri dengan bagaimana laki-laki yang melakukan penindasan pada tokoh perempuan justru harus tumbang dan mati di tangan para perempuan. Penelitian ini bertujuan untuk melihat wacana resistensi perempuan pada hegemoni kekuasaan lakilaki melalui aktivitas domestik yang dilekatkan pada perempuan sebagai peran kulturalnya.

\section{METODE}

Penelitian ini bermaksud memperoleh pemahaman pada wacana perlawanan terhadap idealitas perempuan dalam Film MPEB. Dengan demikian metode penelitian ini mengambil bentuk deskriptif kualitatif dengan pendekatan analisis wacana. Analisis wacana digunakan untuk mempelajari makna pesan yang terdapat dalam sebuah teks ataupun dialog film serta digunakan untuk mempelajari makna pesan yang terdapat pada sebuah wacana ataupun teks film yang diteliti.

Data diperoleh dengan menekankan pada pengamatan terhadap film yang kemudian ditranskripsi terhadap teks dan gambar dalam Film MPEB.

Model analisa yang digunakan adalah analisis wacana model Teun A. Van Dijk. Van Dijk (Sobur, 2009) melihat suatu teks berdasarkan beberapa struktur yang masing-masing bagian saling mendukung. Struktur yang pertama adalah struktur makro, melihat makna keseluruhan dari suatu teks yang diamati dengan cara melihat tema atau topik yang dijadikan dasar dalam suatu peristiwa. Kedua adalah superstruktur, berhubungan dengan kerangka suatu teks dan bagaimana bagian-bagian teks tersusun dalam menjelaskan suatu peristiwa secara utuh. Terakhir adalah struktur, suatu makna wacana yang dapat diteliti dari bagian kecil suatu teks yaitu kalimat, kata dan gambar. 


\section{HASIL DAN DISKUSI}

\section{Sinopsis Film MPEB}

Sesuai dengan judulnya, Film berdurasi 90 menit ini menceritakan empat babak kisah Marlina, seorang janda muda tanpa anak yang dihadapkan pada pilihan untuk tunduk pada dominasi laki-laki atau melawan idealitas sebagai perempuan. Kisah ini dijabarkan secara ringkas sebagai berikut:

Babak 1, The Robery

Diawali perjalanan seorang laki-laki menggunakan kendaraan motor mengarungi padang sabana hingga ke sebuah rumah. Laki-laki itu adalah Markus. Sebelum memasuki rumah, Markus melihat sebuah kuburan atas nama Topan, anak Marlina yang meninggal ketika usia kandungannya 7 bulan. Di dalam rumah dan di hadapan mumi suami Marlina yang tidak lama telah meninggal, Markus mengatakan pada Marlina bahwa ia bersama enam temannya datang untuk merampok harta sekaligus kehormatan Marlina yang telah menjadi janda. Marlina yang diminta memasak sup ayam untuk jamuan makan malam, memasukkan racun dari buah yang disimpannya. Keempat teman Markus mati setelah memakan sup ayam itu. Markus yang menunggu Marlina di kamarnya tidak mengetahui keadaan tersebut. Dalam kondisi tersudut saat dirinya diperkosa oleh Markus, Marlina mengambil senjata Markus dan memenggal kepalanya.

\section{Babak 2, The Journey}

Pagi berikutnya, Marlina memulai perjalanannya menuju kantor polisi. Di sini Marlina bertemu dengan Novi, sahabatnya yang sedang hamil 10 bulan. Bersama dengan Novi, Marlina membawa kepala Markus dan menempuh perjalannya untuk menuntut keadilan bagi dirinya.. Di tengah perjalanan, Frans, teman Markus yang pulang terlebih dahulu menyusul truk yang ditumpangi Marlina. Frans mengamuk setelah mengetahui Markus dan teman-teman yang lain telah mati. Beruntung Marlina sedang beristirahat di atas bukit. Truk yang ia naiki pergi membawa Novi dan penumpang yang lain di bawah ancaman Frans. Perjalanan Marlina pun dilanjutkan menggunakan kuda.

\section{Babak 3, The Confession}

Kepala Markus dititipkan sementara oleh Marlina pada anak pemilik warung makan sesampainya di kantor polisi. Setelah menunggu para polisi selesai bermain pingpong, Marlina menceritakan peristiwa yang ia alami. Namun laporan Marlina tidak bersambut baik. Ia diminta menunggu di rumahnya selama dua sampai tiga hari untuk olah TKP. Dan untuk kasus pemerkosaan yang terjadi padanya, ia diminta menunggu juga selama satu bulan untuk visum sebagai bukti polisi. Dengan kecewa, Marlina menangis di warung makan tempat ia menitipkan kepala Markus. 
Jurnal PRAXIS | Vol. 2 | No. 2 | Maret 2020

\section{Babak 4, The Birth}

Frans yang membawa Novi dan penumpang truk yang lain, menjebak Novi ketika Umbu, suami Novi, menelepon dirinya. Ia mengatakan pada Umbu bahwa Novi berselingkuh dengannya. Umbu, yang mencurigai Novi, karena anaknya tak kunjung lahir, menuduh kandungan Novi sunsang. Dijelaskan bahwa ketika kandungan sunsang artinya bahwa si ibu bermain bersama lelaki lain. Terjebak pada amarah, Umbu meninggalkan Novi padahal Novi ingin meminta pertolongan Umbu untuk Marlina. Di saat sendirian, Novi yang telah diancam Frans, terpaksa menelepon Marlina untuk kembali ke rumahnya. Frans meminta kepala Markus dikembalikan padanya.

Sesampainya di rumah, Frans meminta Novi menyiapkan makan malam, sup ayam. Dengan menahan sakit akibat kontraksi yang dialaminya, Novi memasak sup ayam. Dari dapur ia mendengar Marlina berteriak akibat diperkosa Frans. Pada akhirnya Novi memutuskan mengambil senjata teman Markus yang telah mati, masuk ke dalam kamar, dan memenggal kepala Frans. Novi pun terjatuh dan babak ini diakhiri dengan Marlina membantu Novi melahirkan anaknya yang telah berusia 10 bulan dalam kandungan.
Idealitas Perempuan dalam Peran Kultural

Hubeis (2010) membagi lima peran perempuan dalam pembagian kerja di dalam rumah tangga. Bagi Hubeis, peran yang menempatkan perempuan pada fungsi reproduksi disebut sebagai peran Tradisi atau Kultural. Pada peran ini, perempuan menjalankan fungsinya untuk mengurus rumah tangga, melahirkan, dan mengasuh anak, serta mengayomi suami. Peran ini muncul karena budaya patriarki yang langgeng dalam masyarakat. Pembagian kerja dibedakan secara jelas, yaitu perempuan di dalam rumah (wilayah domestik) dan laki-laki di luar rumah.

Sesuai dengan pendapat Adeney, sebagai kontruksi dari masyarakat patriarkal, perempuan pada umumnya tidak memiliki kuasa atas laki-laki, ia cenderung tunduk pada aturan yang ditetapkan laki-laki. Pada film MPEB ini, peran perempuan sebagai kelas kedua didominasi melalui dua aktivitas, yaitu urusan kasur dan dapur.

\section{Perempuan dan Kasur}

Perempuan ditempatkan sebagai kaum penurut bahkan hanya sebagai objek seksual secara jelas telah diceritakan dalam film ini. Berikut adalah dialog yang menunjukkan laki-laki yang melekatkan perempuan seputar aktivitas kasur: 
Jurnal PRAXIS | Vol. 2 | No. 2 | Maret 2020

Tabel 1. Dialog Tokoh yang Melekatkan Perempuan pada Aktivitas Kasur

\begin{tabular}{|c|c|c|}
\hline Scene & Tokoh & Script \\
\hline \multicolumn{3}{|c|}{ Babak I, The Robbery } \\
\hline \multirow[t]{3}{*}{$\begin{array}{c}1 \\
\text { Di } \\
\text { dalam } \\
\text { rumah } \\
\text { Marlina }\end{array}$} & \multirow[t]{3}{*}{ Markus } & $\begin{array}{l}\text { "Kasian sekali kau. } \\
\text { Janda tidak bisa. } \\
\text { Sebaiknya kalau ada } \\
\text { laki-laki yang masih } \\
\text { mau, jangan terlalu } \\
\text { bapilih.” }\end{array}$ \\
\hline & & $\begin{array}{l}\text { "Kalau masih ada } \\
\text { waktu tidur dengan } \\
\text { kau, kita bertujuh. } \\
\text {...Malam ini kau dapat } \\
\text { bonus, tujuh laki-laki } \\
\text { memang." }\end{array}$ \\
\hline & & $\begin{array}{l}\text { "Heh, seberapa laki- } \\
\text { laki yang kau tiduri? } \\
\text { Hanya dia? Malam ini } \\
\text { kau adalah perempuan } \\
\text { paling beruntung." }\end{array}$ \\
\hline $\begin{array}{c}2 \\
\text { Dapur } \\
\text { Marlina }\end{array}$ & Tamu 1 & $\begin{array}{l}\text { (Suara dari dalam } \\
\text { rumah) } \\
\text { "Dia mengeluh, tak } \\
\text { rasa kencang lagi o. Sa } \\
\text { jawab, tidak usah } \\
\text { begitu, kalau tidak } \\
\text { suka tidak mungkin } \\
\text { longgar, berarti dia } \\
\text { suka to, hahaha..." }\end{array}$ \\
\hline $\begin{array}{c}3 \\
\text { Di } \\
\text { dalam } \\
\text { kamar } \\
\text { Marlina }\end{array}$ & Markus & $\begin{array}{l}\text { " Tunggu, kau duduk. } \\
\text { Kau duduk. Buka... } \\
\text { Buka...Buka..." }\end{array}$ \\
\hline \multicolumn{3}{|c|}{ Babak II, The Journey } \\
\hline $\begin{array}{c}4 \\
\text { Di } \\
\text { pinggir } \\
\text { jalan }\end{array}$ & Novi & 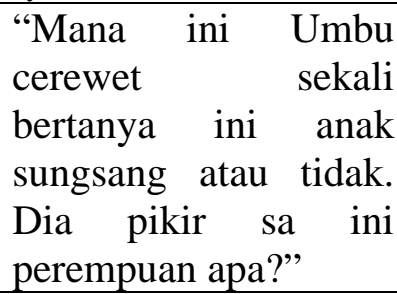 \\
\hline \multicolumn{3}{|c|}{ Babak III, The Confession } \\
\hline $\begin{array}{c}5 \\
\text { Kantor } \\
\text { Polisi }\end{array}$ & Polisis & $\begin{array}{lll}\text { "Kalau dia tua } & \text { dan } \\
\text { kurus, } & \text { kenapa } & \text { kau }\end{array}$ \\
\hline
\end{tabular}

\begin{tabular}{|c|l|l|}
\hline & & $\begin{array}{l}\text { biarkan diperkosa } \\
\text { kau?” }\end{array}$ \\
\hline \multicolumn{2}{|c|}{ Babak IV, The Birth } \\
\hline $\begin{array}{c}\text { Di } \\
\text { pinggir } \\
\text { jalan }\end{array}$ & Umbu & $\begin{array}{l}\text { "Kenapa tidak lahir } \\
\text { juga? Anak kau } \\
\text { sungsang, makanya } \\
\text { tidak mau lahir.” }\end{array}$ \\
\cline { 3 - 4 } & $\begin{array}{l}\text { "Cape cari uang aku, } \\
\text { kau tidak tahan kau } \\
\text { nafsu, pengin tidur } \\
\text { dengan orang lain.” }\end{array}$ \\
& $\begin{array}{l}\text { "Kalau begitu kau } \\
\text { kasih lahir anak itu } \\
\text { sekarang. Sekarang.” }\end{array}$ \\
\hline
\end{tabular}

Rajab (2009) menyatakan bahwa sistem patriarki dimapankan keberlakuannya dengan ditandai adanya hubungan asimetris antara laki-laki dan perempuan. Laki-laki menempati kedudukan yang lebih unggul daripada perempuan baik dalam wilayah domestik maupun wilayah publik. Berdasarkan pernyataan Rajab dan dialog yang muncul dalam film MPEB, sangat jelas bahwa sistem yang dianut masyarakat Sumba, sebagai latar belakang film, adalah patriarki.

Budaya patriarki paling banyak memunculkan konsep kekuasaan yang mendasar yang akhirnya memperlihatkan adanya kekuatan pada pihak laki-laki untuk menguasai ataupun menghegemoni kaum perempuan dalam berbagai situasi (Maryanti, 2016). Kedudukan perempuan di bawah lakilaki ditandai dengan bagaimana laki-laki memberi pengaturan pada perempuan serta menempatkannya pada posisi yang tidak 
bernilai. Hal ini nampak pada bagaimana Markus dengan santai menyampaikan bahwa Marlina akan ditiduri oleh tujuh laki-laki sebagai bonus atas “perampasan” ternak Marlina. Menjadi ironi ketika perempuan dianggap lebih lemah dari laki-laki, namun tidak mendapat perlindungan dari laki-laki.



Gambar 1. Markus menunggu Marlina di kamar dengan gaya mendominasi

Pada gambar 1 ditunjukkan Markus duduk menopang tangan ke belakang dan menyilangkan kaki dengan santai di atas kasur. Di lain sisi, Marlina justru duduk dalam posisi menunduk dan menggenggam tangan di pangkuan. Gambar ini menvisualkan bagaimana dominasi Markus terhadap Marlina di kamar Marlina sendiri.

Berdasar dialog dan visual Markus, dominasi ini seakan ingin mengatakan bahwa "aku memiliki kuasa untuk melakukan apapun secara bebas, tidak peduli kamu suka atau tidak”. Ketidakpedulian akan perempuan ini nampak saat Markus menampik pernyataan Marlina yang membela diri, "Sa, perempuan paling sial sudah malam ini. Hah, Kau ini suka sekali jadi korban.” Pernyataan Markus ini menunjukkan bagaimana perlakuan
Markus adalah hal wajar dan Marlina berlebihan dalam menerimanya.

Tidak saja oleh Markus, film ini juga seakan ingin mengatakan bahwa ketidakadilan ini dilakukan oleh hampir seluruh lapisan masyarakat. Hal ini ditunjukkan ketika Marlina membuat laporan pada polisi. Bukannya segera membantu Marlina menyelesaikan masalah yang diterimanya, aparat kepolisian justru menyudutkan Marlina seakan dia bersalah. Nampak ketika polisi mengatakan, "Kalau dia tua dan kurus, kenapa kau biarkan diperkosa kau?” Persoalan pemaksaan dan pemerkosaan yang terjadi pada Marlina dianggap oleh polisi dibiarkan dan dinikmati Marlina. Film ini menunjukkan bahwa tidak saja perempuan tidak dilindungi oleh laki-laki bahkan oleh aparat polisi sebagai pelindung masyarakat.

Sistem patriarki yang langgeng di masyarakat mendukung perlakuan Markus dan polisi tersebut. Hal ini karena konsep patriarki menempatkan laki-laki sebagai subjek dan perempuan dituntut sebagai objek. Hal ini membuat perempuan memiliki fungsi periferal yang secara keseluruhan berpusat pada laki-laki (Prabasmoro, 2007).

Pada hubungan rumah tangga ketidakadilan ini digambarkan dengan perlakuan Umbu pada Novi, istrinya. Novi yang telah hamil 10 bulan dituduh hamil sungsang. Dijelaskan 
Jurnal PRAXIS | Vol. 2 | No. 2 | Maret 2020

dalam film bahwa perempuan yang hamil sungsang adalah akibat dari selingkuh dengan laki-laki lain. Umbu yang bekerja di tempat yang berbeda tidak mempercayai Novi. Kondisi Novi yang tidak kunjung melahirkan dianggap Umbu bahwa bayi dalam kondisi sungsang. Dan kondisi ini menyebabkan Umbu menuduh Novi berselingkuh ketika Umbu bekerja. Tuduhan ini dilanggengkan oleh Umbu berdasarkan pengalaman tradisi yang menempatkan perempuan sebagai objek. Ketika Umbu mengatakan bahwa dirinya capai bekerja dan Novi justru berselingkuh dengan laki-laki lain menggambarkan bagaimana laki-laki menjadi pusat kehidupan rumah tangga. Apabila terjadi penyelewengan maka letak kesalahan ada pada perempuan.

\section{Perempuan dan Dapur}

Selain fungsi reproduksi, aktivitas domestik yang juga dilekatkan pada perempuan adalah memasak. Pada film ini, perempuan digambarkan sebagai pelayan bagi laki-laki, khususnya berkenaan dengan penyajian makanan. Berikut adalah dialog yang menunjukkan laki-laki yang melekatkan perempuan seputar aktivitas dapur:
Tabel 2. Dialog Tokoh yang Melekatkan Perempuan pada Aktivitas Dapur

\begin{tabular}{|c|c|c|}
\hline Scene & Tokoh & Script \\
\hline \multicolumn{3}{|c|}{ Babak I, The Robbery } \\
\hline \multirow{3}{*}{$\begin{array}{c}1 \\
\text { Di } \\
\text { dalam } \\
\text { rumah } \\
\text { Marlina }\end{array}$} & \multirow[t]{2}{*}{ Markus } & $\begin{array}{l}\text { "Ada sirih? Kopi? Sa } \\
\text { ini tamu” }\end{array}$ \\
\hline & & $\begin{array}{l}\text { "Masih setengah jam, } \\
\text { sebentar lagi tamu- } \\
\text { tamu yang lain datang, } \\
\text { kau masak makan } \\
\text { malam untuk kami." }\end{array}$ \\
\hline & Marlina & $\begin{array}{l}\text { “Kau mau makan } \\
\text { apa?” }\end{array}$ \\
\hline \multirow{2}{*}{$\begin{array}{c}2 \\
\text { Di } \\
\text { dalam } \\
\text { rumah } \\
\text { Marlina, } \\
\text { makan } \\
\text { bersama }\end{array}$} & Tamu 1 & $\begin{array}{l}\text { "Kau pintar sekali } \\
\text { masak" }\end{array}$ \\
\hline & Tamu 2 & $\begin{array}{l}\text { "Nona, ini lebih enak } \\
\text { dari sa bini punya } \\
\text { masakan, tapi dari sa } \\
\text { mama, kau kalah } \\
\text { sedikit." }\end{array}$ \\
\hline \multicolumn{3}{|c|}{ Babak IV, The Birth } \\
\hline \multirow[t]{2}{*}{$\begin{array}{c}3 \\
\text { Di } \\
\text { dalam } \\
\text { rumah } \\
\text { Marlina }\end{array}$} & Frans & $\begin{array}{l}\text { "Kau masak makan } \\
\text { malam dulu. Novi, sa } \\
\text { mau coba kau punya } \\
\text { masak." }\end{array}$ \\
\hline & Novi & “Mau masak apa?” \\
\hline
\end{tabular}

Posisi perempuan dalam ruang domestik menegaskan bahwa perempuan sebagai the second human. Bahkan dalam kehidupan masyarakat, perempuan tidak memiliki akses pada suara publik secara bebas. Hal ini membuat perempuan dengan terpaksa tidak memiliki daya untuk menolak pengaturan yang diterapkan padanya. Seperti yang digambarkan dalam Film MPEB, baik Marlina dan Novi tidak memiliki kuasa untuk menolak perintah Markus dan Frans untuk menyiapkan makanan bagi mereka. Padahal 
posisi Markus dan Frans adalah bukan siapasiapa bagi Marlina dan Novi.

Aktivitas memasak sebagai bagian dari peran perempuan juga digambarkan secara kental melalui percakapan tamu laki-laki. Saat adegan makan bersama, mereka memuji masakan Marlina dan dibandingkan dengan masakan istri serta ibu mereka. Jelas sekali bahwa aktivitas dapur dikonotasikan dengan peran perempuan dalam rumah tangga. Selain memasak, perempuan sebagai pelayan lakilaki juga melekat pada peran perempuan. Hal ini nampak pada gambar 2.

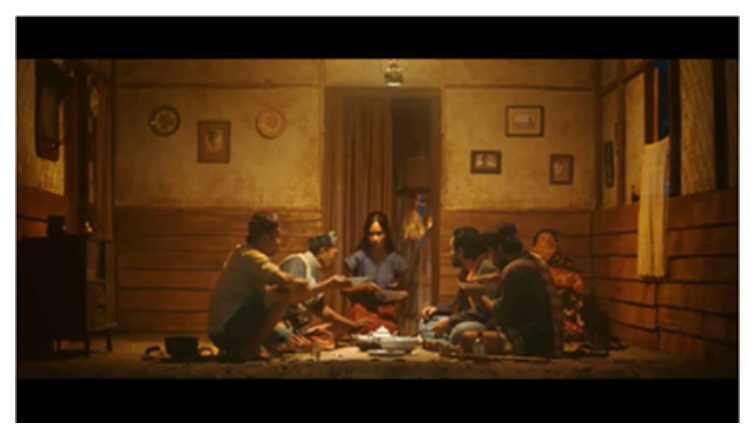

Gambar 2. Marlina melayani tamu dan tamu memegang paha Marlina

Pada gambar tersebut memperlihatkan adegan Marlina yang melayani tamu dengan mengambilkan sop ayam yang baru selesai dimasaknya kemudian disajikan di piring para tamu secara bergantian. Selesai melayani, Marlina duduk tanpa melakukan apa-apa lagi. Hal ini menggambarkan situasi kehidupan rumah tangga yang terjadi pada umumnya, khususnya pada masyarakat tradisi. Bagaimana seorang ibu rumah tangga atau perempuan yang menyiapkan makanan dan melayani jamuan makan tetapi akan makan belakangan setelah para peserta jamuan makan selesai makan.

Tidak saja menjadi pelayan, Marlina harus menerima ketika tamu laki-laki memegang dan menepuk pahanya saat memuji masakan Marlina. Sebagai orang asing yang tidak saling mengenal, jarak personal Marlina dilanggar ketika orang asing menyentuh bagian paha. Adegan ini semakin menegaskan posisi perempuan yang tidak saja sebagai pelayan laki-laki namun juga tidak memiliki daya sebagai objek laki-laki.

Ketidakmampuan Marlina dan Novi dalam melawan ketidakadilan ini bukan semata karena tidak memiliki kemampuan melainkan pada keengganan melawan budaya yang telah mengakar kuat. Langgengnya sistem patriarki telah begitu lekat, hingga perempuan sendiri memandang dirinya sebagai objek laki-laki. Seperti yang dilakukan Marlina dan Novi yang tidak menolak ketika diperintah memasak. Dalam adegan, Marlina berdiri dan menggunakan intonasi tinggi yang menunjukkan dirinya marah, namun dia tetap bertanya, "Kau mau makan apa?” Hal lainnya juga nampak dari cerita Novi, “Mama mantu bilang kalau bayi sungsang berarti kau tukang selingkuh. Kau ini perempuan, jangan kau macammacam...." Cerita Novi tersebut menggambarkan bahwa mama mantunya, 
yang adalah perempuan, juga menyalahkan Novi, sesama perempuan.

Relasi kekuasaan antara yang mendominasi dan yang didominasi dilihat dari bagaimana ideologi yang dibangun laki-laki (kaum yang mendomiasi) membentuk pandangan perempuan (kaum minoritas) menerima hegemoni dominator terhadap inferior. Sesuai dengan thesis Suseno (2010) bahwa kenormalan atau idealitas adalah produk kultural yang kerap digunakan sebagai pelabelan serta pelanggengan dominasi dan kekuasaan. Apa yang dilakukan Marlina, Novi, Markus, Petrus, Frans, Polisi, serta mama mantu Novi tidak berlangsung secara tiba-tiba. Sistem patriarki dilanggengkan melalui peran tradisi yang diturunkan secara terus menerus sehingga memunculkan perilaku salah benar. Pada akhirnya memunculkan kenormalan pada peran kultural perempuan, yaitu pada wilayah domestik, sebagai warga kelas dua, dan menjadi objek laki-laki.

\section{Perlawanan Marlina dan Novi terhadap}

\section{Idealitas Peran Kultural dalam MPEB}

Tidak mudah untuk melawan hegemoni yang telah mengakar kuat. Biarpun melawan dapat dilakukan namun perlawanan tersebut akan dilemahkan. Marlina dan Novi sebagai tokoh perempuan di film ini awalnya dihadirkan sebagai perempuan yang diam, dikekang, dan terbungkam, karakter yang diasosiasikan pada perempuan dalam sistem patriarki. Namun pada akhirnya eksistensi Marlina dan Novi menggambarkan perlawanan yang dilakukan perempuan pada situasi inferior melalui peran kultural yang dilekatkan pada mereka.

Tabel 3. Perlawanan Tokoh pada Peran Kultural Perempuan

\begin{tabular}{|c|c|}
\hline Perlawanan & Gambar \\
\hline $\begin{array}{c}\text { Peran kultural pada } \\
\text { aktivitas dapur }\end{array}$ & \\
& Gambar 3. Marlina memetik buah racun dan memasukkannya ke \\
dalam sup
\end{tabular}




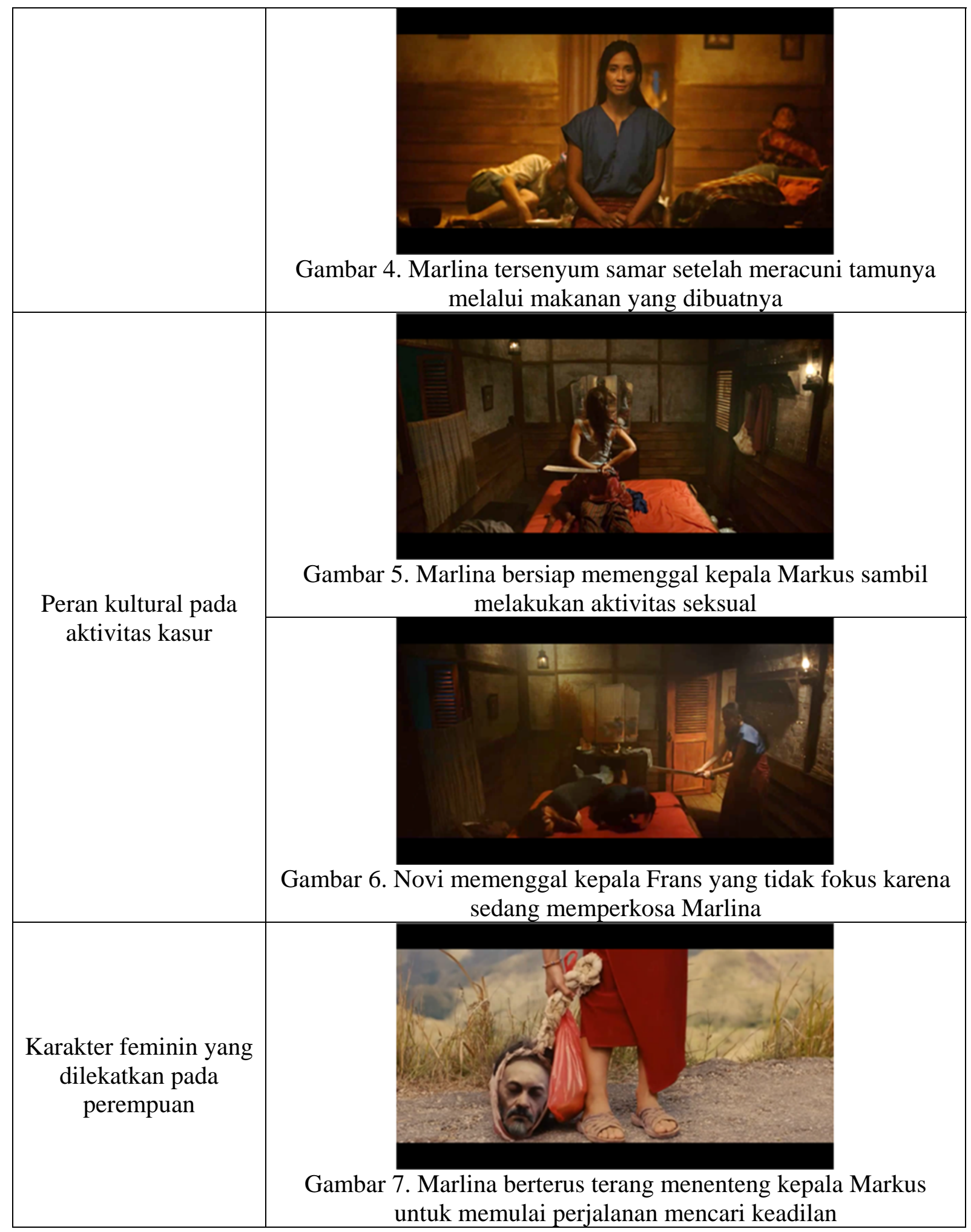




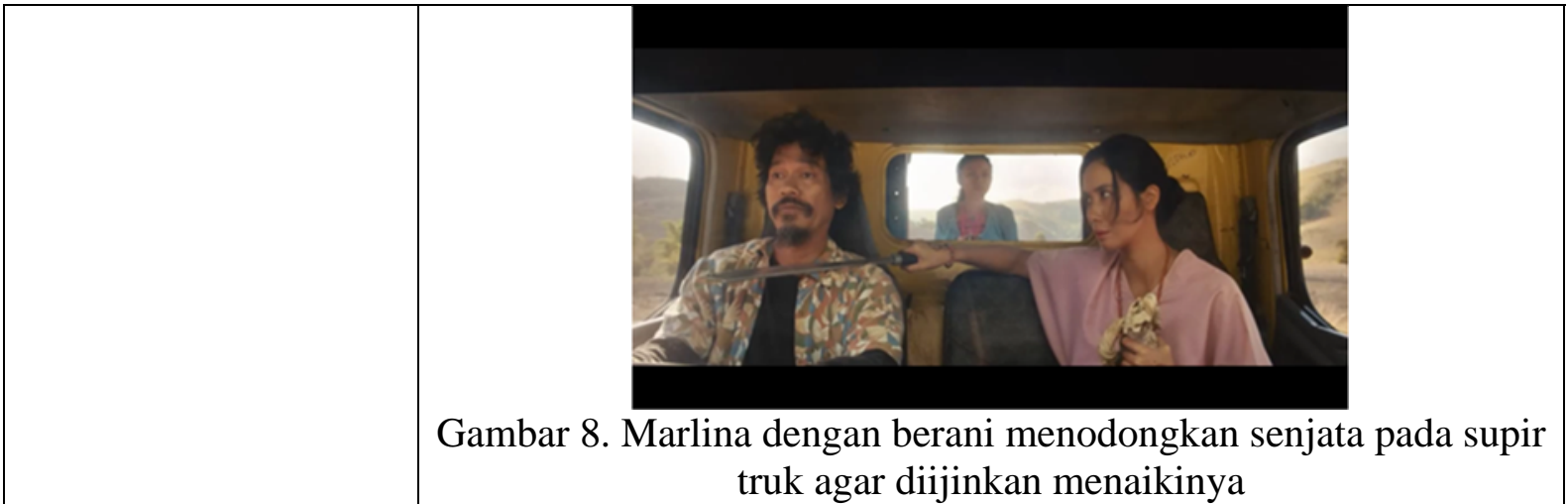

Kramarae (1981, dalam Griffin, 2012) menyatakan bahwa "females are likely to find ways to express themselves outside the dominant public modes of expression used by males in both their verbal conventions and their nonverbal behavior.” Dengan demikian walaupun dalam praktek budaya patriarki, perempuan sebagai kaum marginal tidak memiliki kebebasan atau mengatakan apa yang ingin dikatakan, kapan, dan di mana, Shirley Ardener (dalam Griffin, 2012) menyatakan bahwa keterbungkaman bukan berarti kelompok minoritas sepenuhnya diam.

Hal inilah yang dilakukan oleh Marlina dan Novi, tokoh perempuan dalam film MPEB. Peran kultural yang dianggap normal dilakukan oleh perempuan menjadi alat perlawanan mereka untuk menyuarakan keberdayaannya. Mereka yang harus menjalankan aktivitas kasur dan dapur menjadikan keduanya sebagai kekuatan untuk melakukan perlawanan.

Awalnya, Marlina patuh pada dominasi Markus yang memintanya untuk memasakkan makanan baginya dan tamu yang lain. Seolah Marlina berada pada posisi aman ketika patuh pada dominasi Markus. Namun rasa kawatir pada kemerdekaan dirinya membuat Marlina memutuskan untuk mengambil buah beracun dari kamarnya dan memasukkan pada sup ayam yang dibuatnya. Perlawanan ini semakin ditegaskan dalam gambar 4. Di sini Marlina tersenyum samar sembari duduk berlatar empat tamu laki-laki yang mati karena makanan beracunnya. Ekspresi Marlina terlihat puas dan seolah menggambarkan kemenangan yang telah diraihnya serta mengolok tamu laki-lakinya yang telah jatuh pada rasa masakan yang dipuji mereka.

Sebagai subordinat laki-laki, Marlina juga dihadapkan pada persoalan kasur. Marlina yang memiliki status janda dipaksa untuk bahagia ketika menerima pemerkosaan pada dirinya. Perlakuan yang melanggar batas privasinya mendorong Marlina melawan sebagai upaya penyelamatan diri. Dalam gambar 5, film MPEB memperlihatkan Marlina yang menggunakan kepatuhannya 
Jurnal PRAXIS | Vol. 2 | No. 2 | Maret 2020

untuk beranjak dari persoalannya. Ketika Markus lengah pada sikap Marlina, ia mengambil kesempatan untuk melakukan perlawanan dengan mengambil senjata Markus dan memenggal Markus sembari berhubungan intim.

Namun, perlawanan pada dominasi laki-laki tidak selalu lancar diceritakan dalam film ini. Hal ini merefleksikan situasi sosial sebenarnya bahwa perempuan yang melawan dominasi kekuasaan maka ia juga akan dilemahkan secara fisik dan karakternya. Belum ada kebebasan yang penuh untuk melakukan perlawanan. Seperti yang dilakukan Markus ketika Marlina menolak untuk dicium. Selain mendapatkan tamparan, Markus juga memaksa Marlina untuk memegang alat kelamin Markus. Perlawanan Marlina dilemahkan dengan ditundukkan lebih dalam pada situasi yang tidak menyenangkan.

Hal yang sama juga ditunjukkan oleh Umbu ketika berhadapan dengan Novi. Ketika Umbu menuduh Novi tidak bisa menahan nafsunya, Novi melawan dengan mengatakan "Kau tidak bisa begitu. Kau masih percaya (dengan Frans), jangan bodoh Umbu". Namun perlawanan ini juga dilemahkan secara fisik. Umbu menampar Novi hingga terjatuh dalam situasi Novi hamil 10 bulan. Selain menampar Umbu juga berkata' “ $\mathrm{Kau}$ berani heh, berani kau?” Ungkapan Umbu ini mmperlihatkan bahwa perlawanan Novi mengancam kedudukan Umbu sebagai pemegang kekuasaan. Maka Novi dilemahkan dan ditundukkan secara fisik dan karakternya sebagai perempuan dan perempuan hamil.

Dalam Muted Group Theory milik Kramarae dinyatakan bahwa perempuan akan mencari cara untuk mengekspresikan diri mereka dengan bahasa yang sama yang digunakan lelaki sebagai kaum superior. Hal ini juga yang dilakukan oleh Marlina ketika mencari keadilan bagi dirinya. Menentang karakter feminim yang diasosiasikan pada perempuan, Marlina berani menenteng kepala Markus di ruang publik. Demikian juga ketika ia diteriaki oleh para penumpang truk yang akan Marlina tumpangi.

“Perempuan ni sial saja.”

"Ini tidak merasa bersalah nona, e."

"Hey nona, Kau telepon kantor polisi saja biar jemput kau di sini."

Dengan tak acuh Marlina menodongkan senjata tajam pada sopir truk dan membuat para penumpang yang lain turun. Pada akhirnya mereka membiarkan Marlina pergi menumpang truk tersebut. Nampak bahwa perlawanan Marlina menggunakan bahasa yang biasa digunakan laki-laki untuk dapat mencapai tujuan yaitu berkarakter maskulin. Sifat maskulin diasosiasikan pada peran dan perilaku laki-laki akibat konstruksi masyarakat serta tidak dihubungkan dengan jenis kelamin. Yoon (2009) menyebutkan 
bahwa Maskulinitas Asia ditandai dengan cenderung bersifat pahlawan, memiliki kekuatan, memiliki kekuasaan, dan agresif. Pada gambar 7 dan 8 terlihat bagaimana Marlina menunjukkan sifat maskulin, yaitu menunjukkan kekuatan dan agresifitas. Sifat menjadi pahlawan juga ditunjukkan Marlina sebagai perlawanan pada situasi sosialnya.

“Kalau begitu kenapa kau tetap melapor, polisi bisa apa? Nanti dong kasih salah kau lagi karena bunuh itu penjahat. Padahal kan kau bela diri.”

\section{“Terus harus bagaimana?”}

“Kau bisa ikut dengan saya saja. Kau bisa ke gereja, mengakukan dosa."

"Sa rasa tidak berdosa."

Ketika Marlina menyatakan dirinya tidak merasa berdosa, nampak bahwa marlina menganggap dirinya sedang menegakkan keadilan bagi dirinya. Sisi maskulin heroism dinyatakan Marlina sebagai bentuk perlawanan pada diskriminasi yang diterima olehnya.

Beberapa situasi tersebut digambarkan bagaimana Marlina menunjukkan perlawanan pada tradisi masyarakat patriarki yang menuntut perempuan bersifat feminim. Pada masyarakat patriarki, konstruksi budaya melabeli femininitas perempuan. Feminin dibingkai dalam tubuh perempuan sehingga memaksa mereka untuk terbungkam dan lemah.
Agar dapat menunjukkan eksistensinya, Marlina, sebagai perempuan, menstranslasikan perilakunya ke dalam sistem ekspresi laki-laki yang dipakai masyarakat selama ini. Perilaku ini menunjukkan bahwa film MPEB menegaskan bahwa menjadi feminim dan maskulin adalah pilihan. Tidak ada perempuan yang terlahir feminim atau lakilaki yang terlahir maskulin. Artinya perempuan memiliki hak untuk menjadi maskulin, pun demikian sebaliknya.

\section{SIMPULAN}

Dalam konsep tradisional, sistem patriarki begitu langgeng dengan menempatkan perempuan sebagai sub-ordinat. Namun tidak selamanya perempuan silenced dan powerless. Film MPEB menunjukkan wacana resistensi perempuan terhadap diskriminasi yang diterima oleh mereka. Perlawanan ditunjukkan dengan menggunakan peran kultural sebagai kekuatan mereka berbicara di wilayah publik. Film ini merepresentasikan kekuatan perempuan melalui peran domestik, peran kelas dua, yaitu kasur dan dapur. Perlawanan kedua yang ditunjukkan dalam film ini adalah melalui cara yang umum dilakukan oleh lakilaki dalam melakukan dominasi, yaitu karakter maskulin. Dengan heroism, power, dan agression, kelompok minoritas menggunakan bahasa mayoritas untuk 
menunjukkan eksistensinya di wilayah publik. Pada akhirnya film MPEB tidak hanya menampilkan situasi sosial dalam hegemoni kekuasaan laki-laki tetapi mengangkat wacana perlawanan perempuan pada hegemoni melalui tradisi kultural yang melekat padanya.

\section{DAFTAR PUSTAKA}

Adeney, B. T. (2004). Etika Sosial Lintas Budaya. Yogyakarta: Kanisius.

Griffin, E. M. (2012). A First Look at Communication Theory, Eighth Ed. Boston: McGraw- Hill.

Hubeis, A. V. S. (2010). Perberdayaan Perempuan dari Masa ke Masa. Bogor: IPB Press.

Maryanti, S. (2016). Perlawanan Perempuan dalam Novel Sunda Sandekala. Prosiding Konferensi Internasional Feminisme: Persilangan Identitas, Agensi dan Politik (20 tahun Jurnal Perempuan): 2348-2374. Jakarta, 2324 September 2016: Yayasan Jurnal Perempuan.

Permatasari, D. B. A (2017). Resistensi Tokoh-Tokoh Perempuan terhadap Patriarki dalam Novel Garis Perempuan Karya Sanie B. Kuncoro. Jentera: Jurnal Kajian Sastra, 6(2), 94109.
Prabasmoro, A. P. (2007). Kajian Budaya Feminis: Tubuh, Sastra, dan Budaya Pop. Yogyakarta: Jalasutra.

Rajab, B. (2009). Perempuan dalam Modernisme dan Postmodernisme. Jurnal Sosiohumaniora, 11(03), 1-12.

Sobur, A. (2009) Analisis Teks Media. Suatu Pengantar untuk Analisis Wacana, Analisis Semiotik, dan Analisis Framing. Bandung: Remaja Rosdakarya.

Suseno (2010). Transformasi Politis Filmisasi Sastra Indonesia; Kajian Ekranasi Cerpen Lintah dan Melukis Jendela ke Dalam Film Mereka Bilang, Saya Monyet karya Djenar Maesa Ayu dalam Perspektif Posmodernisme Hutcheon. Thesis yang tidak dipublikasikan, Universitas Gadjah Mada, Yogyakarta.

Yoon, P. J. (2009). Asia Masculinities and Parodic Possibility in Odaiko Solos and Filmic Representations. Asian Music, 40(1), 100-130. 